\title{
Perancangan dan Pembuatan Smart Lighting pada Ruang Kelas berbasis Wireless Sensor Network
}

\author{
Pamungkas Daud \\ Puslit Elektronika dan Telekomunikasi-LIPI \\ pmkdaud@gmail.com \\ Nanang Nasrullah \\ Fakultas Teknik, Jurusan Elektronika \\ Universitas Langlangbuana \\ nanang@gmail.com
}

\author{
Gita Ambar Dini \\ Fakultas Teknik, Jurusan Elektronika \\ Universitas Langlangbuana \\ gita.ambardini@gmail.com
}

\begin{abstract}
Abstrak - Pencahayaan berperan penting terhadap kenyamanan visual dalam proses belajar-mengajar. Sistem pencahayaan cerdas (smart lighting) dirancang untuk kenyamanan visual dan penghematan energi listrik. Untuk penghematan energi listrik smart lighting dirancang dalam satu ruangan, akan dibagi menjadi beberapa sel/titik. Sehingga kontrol lampu diatur oleh masing-masing sel/titik. Lampu yang akan menyala dengan luminasi 250-300 lux, hanya sel/titik yang memiliki hunian. Sedangan sel yang tidak memiliki hunian, tapi disel/ titik yang lain ada hunian, akan menyala dengan luminasi $20 \%$ dari standar. Dan lampu akan mati apabila dalam ruangan tidak memiliki hunian. Kondisi lingkungan seperti cahaya alami, intensitas cahaya interior, dan tingkat hunian dikumpulkan dari sensor PIR dan sensor cahaya BH1750 akan diproses oleh mikrokontroller. Selanjutnya mikrokontroller akan mengeluarkan nilai PWM, sebagai inputan untuk rangkaian dimmer. Rangkaian dimmer digabungkan dengan rangkaian zero crossing detector, untuk mengendalikan beban lampu LED dimmable dengan sumber AC. Sistem smart lighting dengan sistem sel ini mampu mencapai penghematan energi listrik sebesar $50 \%$.
\end{abstract}

Kata kunci - smart lighting, kenyamanan visual, penghematan energi, dimmer $A C$, lampu LED dimmable

\section{Pendahuluan}

Gangguan pencahayaan dapat berupa distribusi cahaya yang kurang merata, intensitas cahaya terlalu kontras yaitu cahaya ruangan terlalu terang maupun terlalu redup akan menyebabkan kelelahan pada mata dan mengurangi konsentrasi belajar.

Sumber cahaya terbesar matahari sebagai sumber cahaya alami dapat dimanfaatkan untuk sumber Energi. Namun, ketersediaan sumber cahaya alami yang tidak konstan karena perubahan cuaca dan permasalahan yang berkaitan dengan kedalaman ruang menyebabkan distribusi cahaya yang masuk ke dalam ruang tidak merata karena ada beberapa bagian dari ruangan yang tidak kebagian sinar cahaya matahari.
Cahaya lampu dapat mendistribusikan cahaya lebih merata dan cahaya yang dihasilkan relatif konstan Manajemen pencahayaan merupakan salah satu teknologi pencahayaan untuk mengatur sistem pencahayaan secara efisien dan ekonomis, mengatur dan memonitor penggunaan lampu dan luminasi untuk tampilan yang optimum untuk memenuhi kenyamanan visual yang sesuai standar dengan menstimulasi pencahayaan ruangan sesuai kondisi dan kebutuhan ruang.

Pembuatan smart lighting sudah banyak dilakukan oleh peneliti lain. Wilyanto, dkk ${ }^{[8]}$ telah membuat sistem pengaturan pencahayaan ruang kuliah menggunakan Jaringan Sensor tanpa Kabel. Abhishek ${ }^{[9]}$ telah membuat sistem peredupan lampu multichannel dengan pengontrolan peredupan melalui web. Thet, $\mathrm{dkk}^{[10]}$, telah membuat Smart Lighting dengan menggunakan sensor secara nirkabel.

Perancangan dan pembuatan Smart Lighting pada ruang kelas ini, berbeda dengan Smart lighting yang sudah ada sebelumnya. Smart lighting ini menggunakan pencahayaan dengan sistem sel. Pada satu ruang kelas dibagi menjadi beberapa sel. Setiap sel mempunyai lampu dan sensor hunian mandiri. Selain itu setiap sel mampu menerima data hunian dari sel yang lain. Kondisi pengaturan Smart Lighting, ada 3 macam, yaitu

1. Lampu akan mati total, ketika tdak ada orang dalam ruangan.

2. Lampu akan redup (50-60 lux), ketika dalam sel tidak terdeteksi hunian, tapi ditempat lain terdeteksi hunian.

3. Lampu akan menyala terang (250-300 lux), ketika dalam sel terdeteksi adanya hunian. 


\section{Metode}

\subsection{Perancangan Perangkat Keras}

Berikut ini adalah diagram blok sistem dari rangkaian Smart Ligting. Sistem ini terdiri dari 2 alat, yaitu rangkaian master dan rangkaian slave.

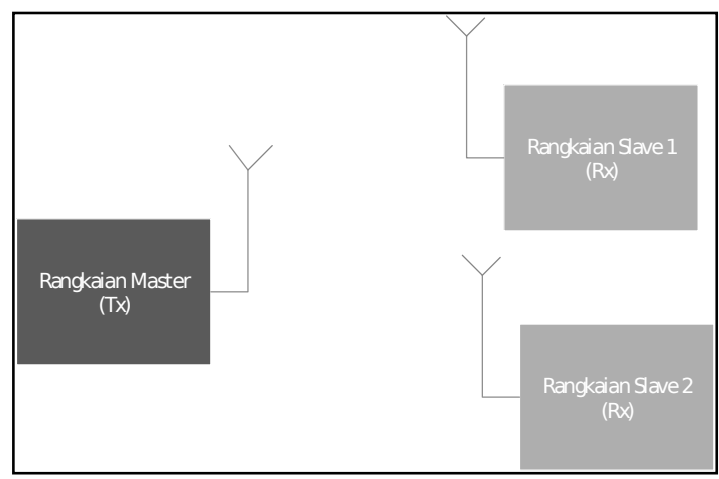

Gambar 1. Blok Diagram sistem

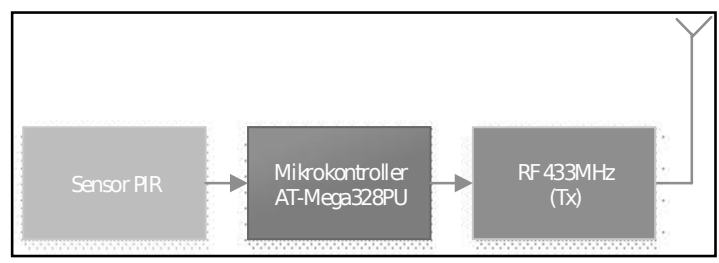

Gambar 2. Blok Diagram Rangkaian Master (Tx)

Rangkaian master terdiri dari mikrokontroller Arduino uno, sensor PIR dan modul RF (Radio Frekuensi). Sensor PIR berfungsi untuk mendeteksi ada tidaknya orang dalam ruang kelas. Mikrokontroller akan mengirimkan kondisi data hunian melalui modul RF $433 \mathrm{MHz}(\mathrm{Tx})$.

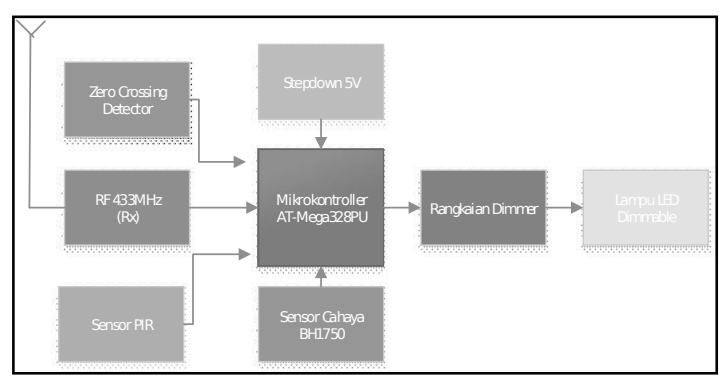

Gambar 3. Blok Diagram Rangkaian Slave (Rx)

Modul stepdown 5V, akan memberikan suplay untuk mikrokontroller, sensor PIR, modul RF, dan rangkaian zero crossing detector. Modul RF (Rx) berfungsi untuk menerima data yang dikirimkan oleh modul RF (Tx). Sensor PIR berfungsi untuk mendeteksi hunian disetiap titik. Sensor BH1750 akan mendeteksi keadaan cahaya yang nantinya akan digunakan sebagai data masukan (input) ke mikrokontroler. Untuk mendeteksi dan mengatur titik nol (zero crossing detector) dari jala-jala listrik untuk digunakan sebagai sinyal acuan digunakan rangkaian zero crossing detector, dimana keluaran dari rangkaian ini nantinya berfungsi sebagai sinyal interupsi pada eksternal Mikrokontroler dan pada akhirnya sinyal PWM yang dapat diatur dibangkitkan sehingga gate triac pada rangkaian dimmer akan terpicu. Rangkaian dimmer berfungsi untuk mengatur redup dan terangnya lampu LED.

\subsection{Perancangan Perangkat Lunak}

Pada rangkaian master, sensor PIR akan mendeteksi hunian dalam ruangan. Ketika ada orang dalam ruangan, maka mikrokontroller akan membuat status data='1234'. Ketika tidak ada orang, maka mikrokontroller akan membuat status data='0000'. Data ini akan dikirim melalui modul RF secara nirkabel. Pada gambar 4. dapat dilihat flow chart dari rangkaian master yang dibuat.

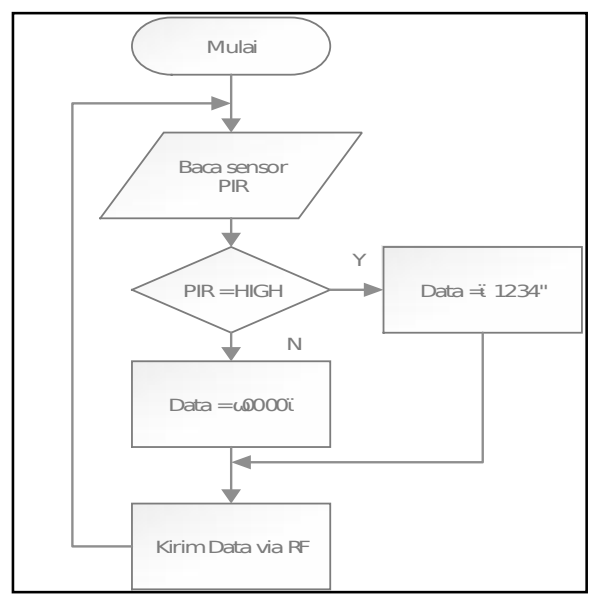

Gambar 4. Flowchart Rangkaian Master (Tx)

Pada rangkaian Slave, data dari rangkaian master yang dikirim secara nirkabel akan diterima, oleh modul $\mathrm{RF}(\mathrm{Rx})$. Kemudian sensor PIR pada rangkaian slave akan mendeteksi hunian per sel/ titik.

Berikut ini adalah flowchart dari rangkaian slave.

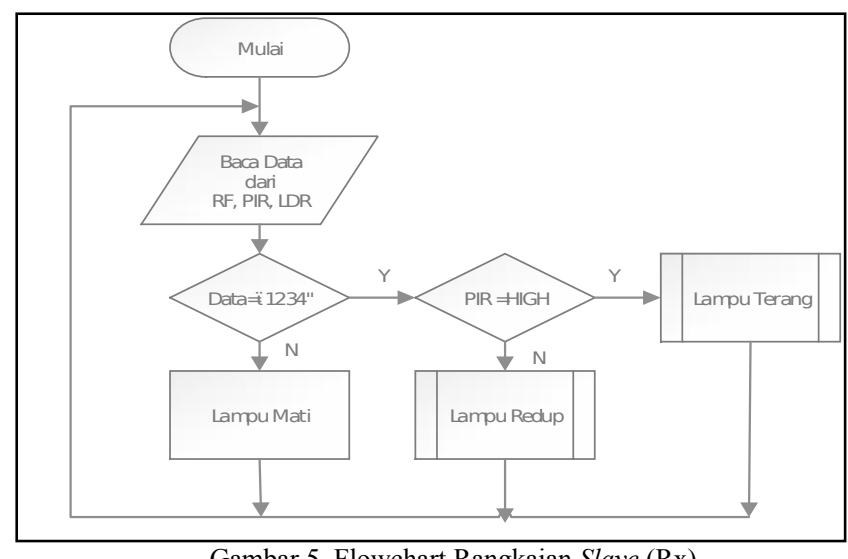

Gambar 5. Flowchart Rangkaian Slave (Rx) 


\subsection{Desain Skematik}

\subsubsection{Rangkaian Sistem Minimum ATMega 328PU}

Rangkaian sistem minimum ini digunakan untuk kontroller dirangkaian master dan slave. Pin yang digunakan pada rangkaian master adalah pin D6, D7 dan D12. Pin D6 dihubungkan dengan pin Out Modul PIR. Pin D7 dihubungkan dengan led merah sebagai lampu indikator. Pin D12 dihubungkan dengan pin Data Modul RF 433MHz, sebagai transceiver (Tx).

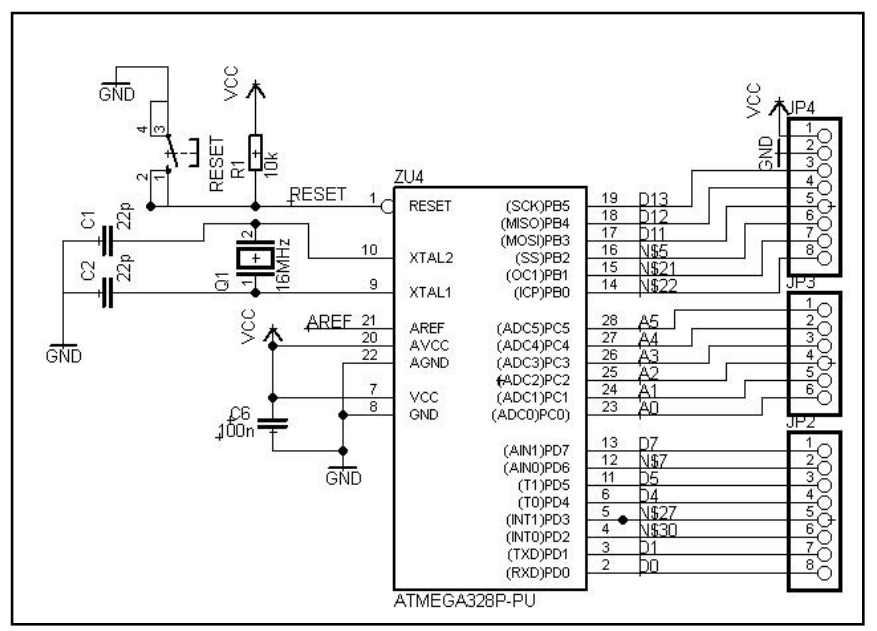

Gambar 6. Skematik Rangkaian Sismin ATMega 328 PU

Pada rangkaian Slave, pin mikrokontroller yang dipakai adalah pin D2, D3, D6, D7, D11, A4 dan A5. Pin D2 disambungkan dengan rangkaian Zero Crossing Detector. Pin D3 sebagai PWM dihubungkan dengan rangkaian dimmer. Pin D6 dihubungkan dengan pin Out Modul PIR. Pin D7 dihubungkan dengan led merah sebagai lampu indikator. Pin D11 dihubungkan dengan pin Data Modul RF 433MHz, yang berfungsi sebagai receiver (Rx). Pin A4 dihubungkan dengan pin SDA dan pin A5 dihubungkan dengan pin SLC pada sensor BH1750.

\subsubsection{Rangkaian Dimmer}

Komponen utama dari rangkaian dimmer ini adalah triac BTA16 yang memiliki rating tegangan sampai dengan 600Volt dan arus maksimum 16A. Antara rangkaian dimmer dan rangkaian lainnya perlu dipisahkan karena tegangan ground-nya berbeda, untuk itu digunakan suatu driver triac MOC3020 yang bersifat optocoupler. Untuk mengaktifkan MOC3020 diperlukan arus dengan nilai maksimum $50 \mathrm{~mA}$. Pada gambar 7., terlihat Skematik rangkaian dimmer.

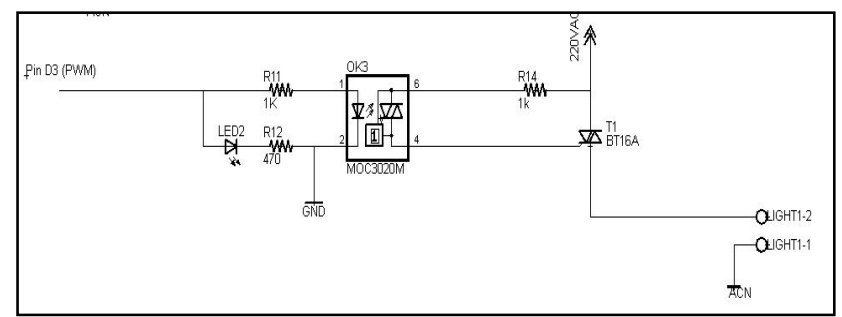

Gambar 7. Skematik Rangkaian Dimmer

\subsubsection{Rangkaian Zero Crossing Detector}

Rangkaian ini digunakan untuk mendeteksi titik nol dari jala-jala listrik untuk dijadikan sinyal acuan yang akan digunakan sebagai interupsi eksternal mikrokontroler. Pada rangkaian ini untuk memicu Gate Triac pada rangkaian Dimmer, digunakan sinyal PWM yang dibangkitkan dan diatur oleh Mikrokontroler.

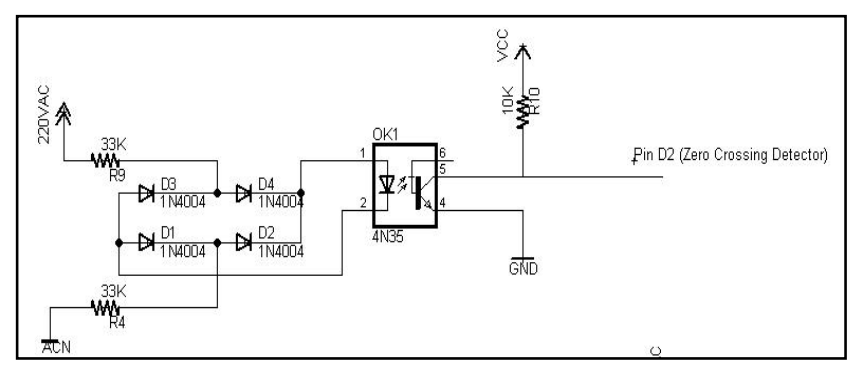

Gambar 8. Skematik Rangkaian Zero Crossing Detector

\section{Hasil dan Diskusi}

\subsection{Perhitungan Batas Cakupan Area Sensor PIR}

Penentuan batas area sensor PIR pada rangkaian Slave, tergantung kepada tinggi ruang kelas. Sensor PIR yang mempunyai sudut pancaran sebesar $110^{\circ}$, dibatasi menjadi $30^{\circ}$. Sehingga batas area sensor tidak terlalu melebar. Rumus untuk mencari besar jari-jari area sensor adalah :

$$
r=\tan \left(15^{\circ}\right) \times \text { tinggi ruangan }
$$

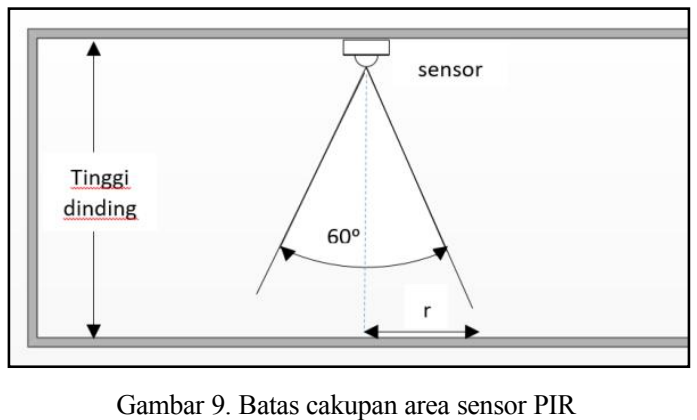

\subsection{Perhitungan Banyak Lampu dan Posisi Penempatan Lampu}

Perencaan besarnya tingkat pencahayaan pada ruang kelas adalah 250 lux. Jika lampu yang digunakan 
mempunyai lumen $840 \mathrm{~lm}$. Maka banyaknya lampu yang diperlukan dalam satu ruang adalah:

$$
\begin{aligned}
& N=\frac{E \times L \times W}{\phi \times L L F \times C u \times n} \\
& N=\frac{250 l \times 2 m \times 2 m}{840 l \times m^{2} \times 0,8 \times 65 \% \times 1} \\
& \quad N=2,289= \pm 2 \text { buah }
\end{aligned}
$$

Berikut ini adalah posisi penempatan lampu pada ruangan $2 \mathrm{~m} \times 2 \mathrm{~m}$.

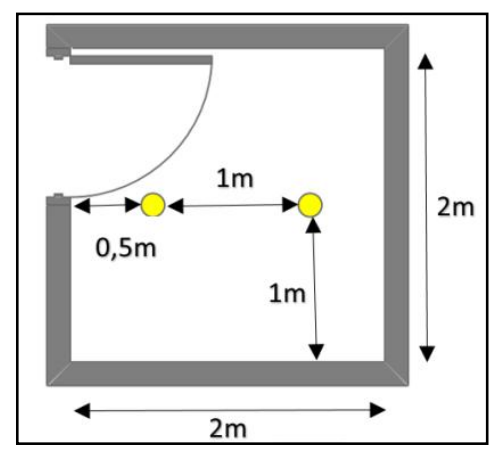

Gambar 10. Posisi Penempatan Lampu

\subsection{Pengujian Sensor PIR}

Pengukuran sensor Pir bertujuan untuk memastikan sensor pir berfungsi dengan baik. Sebelum dilakukan pengukuran, sensor pir disetting dengan cara mengatur waktu jeda (delay time) dan pengaturan sensitivitas.

\begin{tabular}{|c|c|c|c|c|c|c|}
\hline \multirow{2}{*}{$\begin{array}{c}\text { Sudut } \\
\left(\left(^{\circ}\right)\right.\end{array}$} & \multicolumn{6}{|c|}{ Jarak (meter) } \\
\hline & 1 & 2 & 3 & 4 & 5 & 6 \\
\hline-60 & 0 & 0 & 0 & 0 & 0 & 0 \\
\hline-50 & 1 & 0 & 0 & 0 & 0 & 0 \\
\hline-40 & 1 & 1 & 0 & 0 & 0 & 0 \\
\hline-30 & 1 & 1 & 1 & 0 & 0 & 0 \\
\hline-20 & 1 & 1 & 1 & 1 & 0 & 0 \\
\hline-10 & 1 & 1 & 1 & 1 & 1 & 0 \\
\hline 0 & 1 & 1 & 1 & 1 & 1 & 0 \\
\hline 10 & 1 & 1 & 1 & 1 & 1 & 0 \\
\hline 20 & 1 & 1 & 1 & 1 & 0 & 0 \\
\hline 30 & 1 & 1 & 1 & 0 & 0 & 0 \\
\hline 40 & 1 & 1 & 0 & 0 & 0 & 0 \\
\hline 50 & 1 & 0 & 0 & 0 & 0 & 0 \\
\hline 60 & 0 & 0 & 0 & 0 & 0 & 0 \\
\hline
\end{tabular}

Pada Tabel-1, terlihat hasil pengujian dari sensor PIR.

Tabel 1. Hasil pengujian sensor PIR

Dari hasil Pengukuran sensor PIR dapat disimpulkan bahwa sensor PIR mampu mendeteksi keberadaan manusia sampai jarak $5 \mathrm{~m}$ dengan jangkauan sudut $100^{\circ}$.

\subsection{Pengujian Sensor Cahaya BH1750}

Pengujian sensor BH1750 dilakukan dengan cara membandingkan hasil pengukuran intensitas cahaya lux meter LX-1010B dengan sensor BH1750.
Tabel 2. Perbandingan Pengukuran Sensor Cahaya BH1750 dan Lux Meter LX-1010B

\begin{tabular}{|c|c|c|c|}
\hline $\begin{array}{c}\text { Duty Cycle } \\
\text { PWM (\%) }\end{array}$ & $\begin{array}{c}\text { Sensor BH1750 } \\
(\mathbf{l x )}\end{array}$ & $\begin{array}{c}\text { Lux Meter } \\
\mathbf{( 1 x )}\end{array}$ & $\begin{array}{c}\text { Kesalahan } \\
\mathbf{( \% )}\end{array}$ \\
\hline 5 & 46 & 42 & 9,5 \\
\hline 10 & 108 & 108 & 0 \\
\hline 15 & 170 & 177 & -4 \\
\hline 20 & 198 & 179 & 10,6 \\
\hline 25 & 184 & 171 & 7,6 \\
\hline 30 & 204 & 204 & 0 \\
\hline 35 & 316 & 296 & 6,8 \\
\hline 40 & 430 & 415 & 3,6 \\
\hline 45 & 519 & 477 & 8,8 \\
\hline 50 & 583 & 535 & 9,0 \\
\hline 55 & 635 & 573 & 10,8 \\
\hline 60 & 710 & 638 & 11,3 \\
\hline 65 & 750 & 728 & 3,0 \\
\hline 70 & 760 & 755 & 0,7 \\
\hline 75 & 781 & 770 & 1,4 \\
\hline 80 & 798 & 789 & 1,1 \\
\hline 85 & 816 & 809 & 0,9 \\
\hline 90 & 827 & 815 & 1,5 \\
\hline 95 & 839 & 830 & 1,1 \\
\hline
\end{tabular}

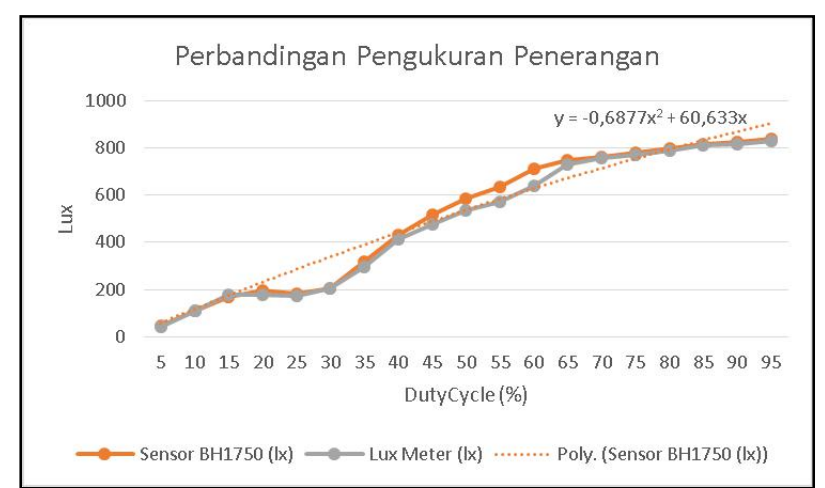

Gambar 11. Grafik Perbandingan Pengukuran Penerangan antara Lux Meter Type LX1010B dengan Sensor BH1750

Kesalahan minimal pengukuran dengan menggunakan sensor cahaya BH1750 yaitu $0 \%$, pada saat duty cycle $10 \%$ dan $30 \%$. Sedangkan persentasi kesalahan maksimum yaitu sebesar $11,3 \%$ pada saat duty cycle $60 \%$.

\subsection{Pengujian Modul RF 433Mhz}

Pengujian modul RF 433Mhz bertujuan untuk memastikan data terkirim sampai tujuan. Pengujian ini menggunakan dua mikrokontroller. Satu mikrokontroller disambungkan dengan modul Transmitter RF 433MHz. dan yang satu lagi dihubungkan dengan modul Receiver RF 433MHz.

Tabel 3. Pengujian Modul RF 433MHz

\begin{tabular}{|c|c|}
\hline Jarak (m) & Pengiriman data \\
\hline 5 & Terkirim \\
\hline 10 & Terkirim \\
\hline 15 & Terkirim \\
\hline 20 & Terkirim \\
\hline
\end{tabular}




\subsection{Pengujian Rangkaian Dimmer}

Pengujian rangkaian dimmer dilakukan untuk mengecek lampu led apakah menyala stabil atau berkedip. Hasil pengukuran tegangan output, dan arus output dari rangkaian dimmer yang nantinya digunakan mengatur intensitas cahaya lampu, bisa dilihat pada Tabel-4.

Tabel 4.Pengukuran Arus dan Tegangan pada Dimmer

\begin{tabular}{|c|c|c|c|c|}
\hline $\begin{array}{c}\text { Duty Cycle } \\
\text { PWM (\%) }\end{array}$ & $\begin{array}{c}\text { Arus } \\
(\mathbf{A})\end{array}$ & $\begin{array}{c}\text { Tegangan } \\
(\mathbf{V})\end{array}$ & $\begin{array}{c}\text { Daya } \\
(\mathbf{W})\end{array}$ & $\begin{array}{c}\text { Kondisi } \\
\text { lampu }\end{array}$ \\
\hline 10 & 0,044 & 8,6 & 0,378 & $\begin{array}{c}\text { Menyala } \\
\text { stabil }\end{array}$ \\
\hline 20 & 0,044 & 26,9 & 1,184 & $\begin{array}{c}\text { Menyala } \\
\text { stabil }\end{array}$ \\
\hline 30 & 0,044 & 45,1 & 1,984 & $\begin{array}{c}\text { Menyala } \\
\text { stabil }\end{array}$ \\
\hline 40 & 0,044 & 86,4 & 3,802 & $\begin{array}{c}\text { Menyala } \\
\text { stabil }\end{array}$ \\
\hline 50 & 0,044 & 148,2 & 5,069 & $\begin{array}{c}\text { Menyala } \\
\text { stabil }\end{array}$ \\
\hline 60 & 0,044 & 115,2 & 6,512 & $\begin{array}{c}\text { Menyala } \\
\text { stabil }\end{array}$ \\
\hline 70 & 0,044 & 184,5 & 8,118 & $\begin{array}{c}\text { Menyala } \\
\text { stabil }\end{array}$ \\
\hline 80 & 0,044 & 196,1 & 8,628 & $\begin{array}{c}\text { Menyala } \\
\text { stabil }\end{array}$ \\
\hline 90 & 0,044 & 208,2 & 9,161 & $\begin{array}{c}\text { Menyala } \\
\text { stabil }\end{array}$ \\
\hline 100 & 0,044 & 217,5 & 9,570 & $\begin{array}{c}\text { Menyala } \\
\text { stabil }\end{array}$ \\
\hline
\end{tabular}

\subsection{Pengujian Seluruh Rangkaian}

Pengujian seluruh rangkaian ini untuk mengetahui apakah pembuatan Smart Lightingpada ruang kelas ini, berhasil atau tidak. Untuk mengetahui kondisi hunian di ruangan, dicek oleh sensor pir yang dipasang di rangkaian Master. Sedangkan konsisi hunian di sel di cek oleh sensor pir yang ada di rangkaian slave masingmasing tempat. Kondisi hunian ruangan dikirim ke rangkaian slave melalui tranmisi RF (Radio Frekuensi). Berikut hasil pengujian dari seluruh rangkaian.

Tabel 5. Hasil Pengujian Seluruh Rangkaian

\begin{tabular}{|c|c|c|c|c|}
\hline $\begin{array}{c}\text { Kondisi } \\
\text { Hunian di } \\
\text { Ruangan }\end{array}$ & $\begin{array}{c}\text { Kondisi } \\
\text { hunian } \\
\text { di Sel }\end{array}$ & $\begin{array}{c}\text { Kondisi } \\
\text { seharusnya }\end{array}$ & $\begin{array}{c}\text { Kondisi } \\
\text { yang } \\
\text { Terjadi }\end{array}$ & Keterangan \\
\hline 0 & 0 & Lampu mati & $\begin{array}{c}\text { Lampu } \\
\text { Mati }\end{array}$ & $\begin{array}{c}\text { Sudah } \\
\text { sesuai }\end{array}$ \\
\hline 0 & 1 & $\begin{array}{c}\text { Lampu } \\
\text { menyala }\end{array}$ & $\begin{array}{c}\text { Lampu } \\
\text { menyala } \\
\text { stabil }\end{array}$ & $\begin{array}{c}\text { Sudah } \\
\text { sesuai }\end{array}$ \\
\hline 1 & 0 & $\begin{array}{c}\text { Lampu } \\
\text { menyala } \\
20 \%\end{array}$ & $\begin{array}{c}\text { Lampu } \\
\text { berkedip- } \\
\text { kedip }\end{array}$ & $\begin{array}{c}\text { Belum } \\
\text { sesuai }\end{array}$ \\
\hline 1 & 1 & $\begin{array}{c}\text { Lampu } \\
\text { menyala }\end{array}$ & $\begin{array}{c}\text { Lampu } \\
\text { menyala } \\
\text { stabil }\end{array}$ & $\begin{array}{c}\text { Sudah } \\
\text { sesuai }\end{array}$ \\
\hline
\end{tabular}

Hasil pengujian seluruh rangkaian pada Tabel 5 ada 1 kondisi yang belum sesuai, yaitu pada saat kondisi hunian di sel tidak ada, sementara di sel lain terdapat hunian, maka seharusnya lampu menyala 20\% konstan. Namun kenyataannya lampu tidak menyala konstan (berkedip-kedip). Sehingga perlu dicek rangkaian dimmer pada kondisi hunian di sel lain terdeteksi sedangakam kondisi hunian di sel tidak terdeteksi.

Tabel 6. Pengujian Rangkaian Dimmer pada saat kondisi hunian di sel lain terdeteksi sedangakam kondisi hunian di sel tidak terdeteksi

\begin{tabular}{|c|c|}
\hline Duty Cycle PWM (\%) & Kondisi lampu \\
\hline 10 & Berkedip \\
\hline 20 & Berkedip \\
\hline 30 & Berkedip \\
\hline 40 & Berkedip \\
\hline 50 & Berkedip \\
\hline 60 & Berkedip \\
\hline 70 & Menyala Stabil \\
\hline 80 & Menyala Stabil \\
\hline 90 & Menyala Stabil \\
\hline 95 & Menyala Stabil \\
\hline 100 & Menyala Stabil \\
\hline
\end{tabular}

Dari hasil pengujian pada Tabel 6 kita bisa mengetahui bahwa dimmer menyala stabil pada saat duty cycle $\mathrm{PWM}>=70 \%$

\subsection{Pengukuran Tingkat Penerangan}

Pengukuran tingkat penerangan dilakukan pada setiap titik, seperti pada gambar 4.4. Pengukuran dilakukan pada saat ada hunian (semua lampu menyala) dengan menggunakan lux meter LX-1010B.Hasil Pengukuran bisa dilihat pada Tabel-7.

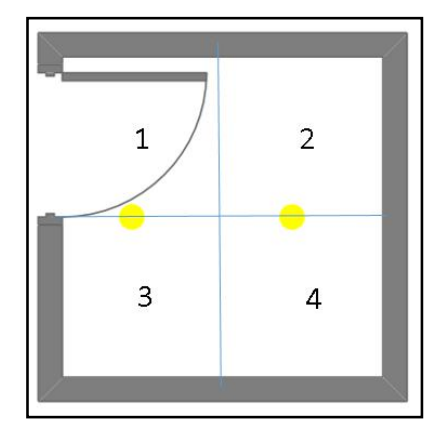

Gambar 12. Posisi Titik Pengukuran Penerangan

Tabel 7. Hasil Pengukuran Tingkat Penerangan pada tiap Titik

\begin{tabular}{|c|c|}
\hline Titik & Tingkat Penerangan (Lux) \\
\hline 1 & 252 \\
\hline 2 & 255 \\
\hline 3 & 251 \\
\hline 4 & 253 \\
\hline
\end{tabular}




\subsection{Analisa Perbandingan Pemakaian Energi Listrik}

Berikut ini adalah hasil analisa dari pemakaian energy listrik dengan menggunakan

Tabel 8. Pengukuran Besarnya Cahaya Alami Yang Masuk Pada Ruang Kelas

\begin{tabular}{|c|c|c|c|c|c|c|}
\hline & \multicolumn{7}{|c|}{ Hari Ke } & $\begin{array}{c}\text { Rata2 } \\
\text { penerangan (lx) }\end{array}$ \\
\hline Jam & $\mathbf{1}$ & $\mathbf{2}$ & $\mathbf{3}$ & $\mathbf{4}$ & $\mathbf{5}$ & 106,60 \\
\hline 7.00 & 117 & 100 & 112 & 108 & 96 & 105,20 \\
\hline 8.00 & 90 & 121 & 114 & 101 & 100 & 106,20 \\
\hline 9.00 & 119 & 102 & 121 & 92 & 97 & 125,60 \\
\hline 10.00 & 130 & 155 & 120 & 115 & 108 & 133,40 \\
\hline 11.00 & 136 & 158 & 191 & 110 & 144 & 133,30 \\
\hline 12.00 & 134 & 136 & 131 & 111 & 154 & 177,40 \\
\hline 13.00 & 182 & 189 & 193 & 159 & 164 & 146,00 \\
\hline 14.00 & 133 & 150 & 167 & 138 & 142 & 148,00 \\
\hline 15.00 & 133 & 147 & 158 & 155 & 147 & 131,29 \\
\hline \multicolumn{7}{|c|}{ Rata-rata Luminasi (lx) } \\
\hline
\end{tabular}

Berikut ini adalah perhitungan iluminasi (tingkat penerangan) cahaya buatan yang diperlukan:

$$
\begin{aligned}
& E_{\text {buatan }}=(250 l x-131,25 l x) \\
&(3) \\
&= 118,71 l x=118,71 \text { lumen } / \mathrm{m}^{2} \\
& F_{\text {buatan }}= E_{\text {buatan }} \times \text { Luas Ruangan } \\
&=118,71 \text { lumen } / \mathrm{m}^{2} \times 4 \mathrm{~m}^{2} \\
&=474,84 \text { lumen }
\end{aligned}
$$

Dengan menggunakan smart lighting, untuk menghasilkan cahaya buatan sebesar 474,88 lumen membutuhkan nilai pwm dengan duty cycle sebesar $45 \%$ (dari tabel 2). Besar daya lampu pada saat duty cycle $45 \%$ adalah \pm 5 watt.

Berikut ini adalah perbandingan perhitungan energy listrik dengan menggunakan smart lighting dan tanpa smart lighting. Dengan asusmsi pemakaian lampu per hari adalah 8 jam

\begin{tabular}{|l|l|}
\hline Smart Lighting & Tanpa Smart Lighting \\
\hline $\mathrm{E}$ & $\mathrm{E}$ \\
$=5 \mathrm{~W} \times 8 \mathrm{jam}$ & $=10 \mathrm{~W} \times 8 \mathrm{jam}$ \\
$\mathrm{E}=40 \mathrm{Kh}$ & $\mathrm{E}=80 \mathrm{Kh}$ \\
\hline
\end{tabular}

Perbandingan perhitungan diatas membuktikan bahwa dengan menggunakan smart lighting, mampu mengurangi energy listrik hingga 50\%

\section{Kesimpulan}

Perancangan dan pembuatan Smart Lighting pada Ruang Kelas dengan berbasis Wireless Network Sensor telah selesai dibuat, berikut ini beberapa kesimpulan yang bisa diambil :

1. Lampu menyala terang dengan iluminasi \pm 250 lux pada saat ada hunian dalam sel.

2. Pada saat tidak ada hunian di sel setempat, tapi di sel lain ada hunian, lampu yang harusnya menyala redup 50 lux, belum berhasil.

3. Dengan menggunakan Smart Lighting konsumsi energi listrik dapat dikurangi setengahnya

\section{Daftar Pustaka}

[1] Latifah, Nur Laela. 2015. Fisika Bangunan 2. Jakarta. Penerbit Griya Kreasi

[2] Kadir, Abdul. 2018. From Zero To A Pro: Arduino. Yogyakarta: Penerbit Andi.

[3] DKI Jakarta, Pemprop. 2012. Sistem Pencahayaan Vol. 3. Jakarta

[4] Schawartz, Marco. 2014. Arduino Home Automation Projects. Birmingham, UK. Packt Publising.

[5] Santoso, Hari. 2017. Monster Arduino Ver 2. Malang

[6] Wilyanto, Firdaus. 2017. Sistem Pengaturan Pencahayaan Pada Ruang Kuliah Untuk Mendukung Program Hemat Energi Berbasis Wireless Sensor Network. Prosiding SNATIF K e-4. ISBN: 978-602-1180-50-1

[7] Ketut, Darminta. 2016. Rancang Bangun Sistem Kontrol Cahaya Lampu Berbasis Mikrokontroler Atmega32. JURNAL LOGIC. VOL. 16. NO. 2. JULI 2016

[8] Gopal M, Venu. 2016. Controlling Multiple RF Receivers by Universal RF Transmitter https://www.engineersgarage.com/contribution/mul tiple-rf-receivers-controlled-universal-rf-transmitter,

[9] Abhishek123. 2018. "Multichannel Wireless Light Dimmer",

https://www.instructables.com/id/Multichannel-

Wireless-Light-Dimmer/

[10] Thet, Lwin Myo. 2017. " A Smart Lighting System using Wirelesss Sensor Actuator Network". London, UK. Intelegent System Conference https://www.researchgate.net/publication/32402185 5 A smart lighting system using wireless sensor actuator_network 